\title{
The Symbolism of Hokke-Proper (II)
}

A Biocentric Drama upon the Stage in the Middle-Heaven (I)

\section{KOTANI Yukio}

These are the unknown accomplishments (from the years ca 1933-1963 ${ }^{1)}$ ) of a Japanese private scholar, Hanjirō Tominaga(富永半次郎²), (1883-1965), who tried, on the basis of his own practical exercise of Śākyamuni's teachings and of his own verification of sanskrit and pali texts, to sift out what were thought to be original parts of Hokke (Lotus Sütra) from the annexed complete set of recurrent prajñā thoughts. It consists of only 6 chapters: Introduction, Skilful Access, Contemplation of a Stūpa, Gushing out of 60.000 Bodhisattvas, Measuring of Merits of Tathāgata and Entrusting of Saddharma.

The following is a paraphrased explanation of the sūtra's title ${ }^{3)}$ :

[Saddamma (of a man's Buddha-like judgement)]〈sat〉 (true being) appears indeed in an individual as objective existence, the original essence of a $\langle$ dhamma $\rangle$ is strictly subjective because of its being judgement.

[Pundariaika (in the mental process)] What has been traditionally called $\langle$ mind $\rangle$ is really nothing but the fruit in which one has concepionally fixed this mental process.

[Sūta (the text, which explains the ground and the necessity of a primordial creation with practical methodologies themselves). Under the adverse impetus of a wrong view, which the two yānas and the third yāna held on the 〈saddhamma〉 as objective, the author of Lotus Sütra Proper (根本法華) corrected the error throughout. That is the very theme of this sūtra.

Firstly the sūtra's title presents $\langle$ Saddhamma $\rangle$, and that indicates the main point of the 〈Saddhamma as subject, and also suggests this point as an idiom by having it followed by the significant term 〈Pundarika tive word for the India intelligentsia that it suggests to the hearers of this sūtra without fail a certain common association and makes them anticipate a sequence as follows: Brahma - Veda - Pundarīka - Ākāśa - Ātman. 
The author induces them along these expectations as the story advances, and he baffles them suddenly, - as soon as it arrives at the end of the chapter of $\langle$ Contemplation of a Stūpa〉 and the beginning of 〈Bodhisattvas' Gushing out of the Earth $\rangle$, by absolving and dissipating traditional mannerisms by means of dexterous plots full of symbolisms: Buddha - Saddharma - Puṇạaīka - Ākāśa Bodhisattva ${ }^{4}$.

For the historical background of its composition, various problems in the ancient Indian Buddhist assemblage (samgha) of the Christian era must be considered.: the teachings left behind by Buddha, misunderstandings of His successive disciples about them, schisms according to the opposing opinions, the Edicts by King Aśoka, the recurrence of nirvana thought and the question of right or wrong about the worship of stūpa. Tominaga assumed an unknown bhikșu, who could create a drama with multivocal symbolisms in order to manifest Buddha- like phenomena, even by remodelling the non-Buddhist, indigenous sources of Chāndogya-Upanișad, Rāmāyaṇa and Sāmkhya philosophy. Its outline is as follows:

\section{Introduction - Skilful Access}

Once upon a time the Bhagavat was staying at Rājagriha, on the Gridhrakūtamountain, with a numerous assemblage of monks ... surrounded, attended, venerated by them. He sat cross-legged and at this time entered into a mental attitude beyond description, the intense meditation, called 〈ananta- nirdeśa-pratisthāna (that is, mental state against infinite expositions). On looking aghast at this unprecedented appearance, that both his body and his mind was motionless, they were all surprised and wondered why He entered into the mysterious meditation.

In the beginning of the next chapter of 〈Skilful Access〉 the Bhagavat rises up, holding remembrance and intelligence of the intense meditation, and speaks to Śāriputra about an incomprehensible difficulty of only one Buddhist yāna (vehicle) for the believers of the two yānas and the third yāna. Thus occurs to each mind the question: "What is Buddha?, the answer to which is the very theme of the next chapter of $\langle$ Contemplation of Ratna-Stūpa $\rangle$. 


\section{Development}

"Then there arose a Stûpa, consisting of seven precious substances, from the place of the earth opposite the Lord, the assembly being in the middle, a Stûpa five hundred yoganas in height and proportionate in circumference." (as translated.by H.Kern ${ }^{5}$ ) The 〈ratna $\rangle$ of 〈ratna-stūpa $\rangle$ signifies the merits of tri-ratna (three jewels): Buddha, Dharma and Bhukșu.

Then, why on earth did stūpa come to be an object of reverence as well as Buddha? ... Even if one actually enshrined the relic, it must have come naturally into question in the Buddhist samgha, how it ought to be to deify it truly, not to be confined to being the result of a simple ceremony. As for the śarīra(relic) of Śākya, it is nothing but the dharma, which he left behind. His judgements or acts in his lifetime are in other words saddharma, but after His death it remained a single dharma, since the assurer of it did not exist anymore. Furthermore, as for Śākya, there existed nothing but this dharma on the part of the samgha, which depended only upon the mind of bhikșus. Inasmuch as Buddha is Dharma, which depends upon bhikșus, 〈the Contemplation of Stūpa〉 ought to be interpreted in such a context. In short, the stūpa, as symbol of the bequeathed dharma of Buddha, ought to be contemplated in their minds. The question is whether a bhikșu can become a Buddha or not. We ought to pay attention to the insinuative meaning of 〈five $\rangle$ of 〈five hundred yojanas, by relating all the mental events to the working of five skandha (aggregate). The living Dharma during the Buddha's lifetime, i.e. saddharma, became, after His death, mere objectively fixed dharma in the memory of many bhikșus, which were in various ways modified, degraded and transferred through the opposing opinions, and schisms of sects to the anonymous author of Lotus Sütra Proper, and he intended, in this chapter, to rectify the distorted views on Buddha and dharma in the samghas' bhikṣus, and to make their stereotyped dharma a truly living one. Here we have suddenly śabda (an authoritative voice), affirmative for the preaching of Buddha, from within the stūpa: "sādhu, sādhu bhagavan Śākyamune subhāṣita te 'yam Saddharmapuṇdarīko dharma-paryāyah," (Excellent, excellent, Lord Sâkyamuni, thou hast well expounded this Dharmaparyâya of the Lotus of the True Law. ${ }^{6}$ ) Except the traditionally Indian word of 〈puṇariaika (a white lotus, symbolising excel- 
lent mind), almost all words derive from the Aśoka's Edict (Calcutta Bairat).

So the main point is: by way of what sort of circumstances becomes 〈pundarika〉 $\langle$ saddharma $\rangle$; and it is solely for this, that Bhagavat Śākya preached in various ways 〈for a sole object to open the eyes of creatures for the sight of Tathāgata-knowledge $\rangle$.

Removal of two pieces - crushing of a logocentric conception

Logocentricity is an antonym of biocentricity, which we use as subtitle of this study. According to the definition ${ }^{7)}$ of Ludwig Klages (1872-1956), the former is characterised by the overestimation of conscience, calculation and mechanic causality on the basis of will and grasping comprehension.

Now, the owner of glorifying utterance from within the stūpa is a dead Buddha, Prabhūtaratna Tathāgata. The preaching Buddha explains to Mahāpratibhāna the former's long-fostered wish during his life-time, namely to have 〈a stūpa of ātmabhāva-vigraha (perfect stūpa to the memory of his soul) erected and to emerge, emitting a śabda, wherever the saddharma is preached, and in addition, under grave condition, to have all his other selves in ten directions assembled.

So the Bhagavat emits a streak of white ray from his brow ,illuminating all the buddhas of fifty hundred thousand koti nayuta worlds of ten directions, equal to the Gangā...They all send their respective messengers to the Bhagavat, consenting to open the stūpa. Then He ascends to the stūpa in the Middle-Heaven, removes two pieces of the stūpa by scooping out by the right $(=$ able $)$ hand in its center - symbolising the removal of opposing two concepts, in order to show a Whole Unity-, and, welcomed by the Prabhūtaratna shares the semi-seat with him. Consenting the assembly on the earth to ascend to contemplate the two Buddhas, the living Buddha makes by his growth of idealising power the four audiences rise up to the MiddleHeaven. Here is then accomplished a right theoretical contemplation of what is Buddha.

\section{Climax - a biocentric drama}

So the Bhagavat proclaims His view, "Who of ye can make manifest the Saddharma Puṇariaika Dharma Paryāya in this world? I will entrust this to a quali- 
fied one before my death. Now it is justly high time for that,"

After Mahāpratibhāna, five hundred scholared bhikshus in the assembly accord with the proposal, hoping to do in another worlds. Just then bodhisattvas from other worlds stand up, and after having joined their hands and worshipped, beg the Bhagavat to permit them to do the missionary work in this world. As soon as He thunders, "Cut it out, ye bodhisattvas!", the earth quivers and splits everywhere, and from every rip immeasurable bodhisattvas emerge from underneath. They have remained under the earth, in the ākāśa world. After their appearance they bow to all the bodhisattvas, fifty-antara (= inner) - kalpa (= incidents of five skandha's 〈samskāra $)$ elapse, during which both the Bhagavat and four audiences remain solely silent as a symptom that neither active nor passive contemplation works owing to

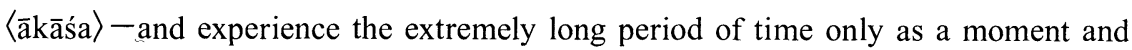
come to see this world, being amid the ākāśa and everywhere, filled with bodhisattvas. Here we find for the first time a complete working of samskāra, as delicately symbolised 〈puṇdarīka〉, i.e. a vivid working of enlightened experience is manifested. And He discloses to Maitreyī the identity of innumerable ākāśa-bodhisattvas, anyone of whom he has never seen before.

This scene, as well as that with the appearance of stūpa, is what we call a biocentric drama on the basis of symbolical thinking. In the center of the question is the unconscious process of a thinking organism with metamorphosis, that seems indeed a fantastic, irrational mysticism in the so called Tiefenpsychologie. But that which plays an important part behind the scenes is $\langle$ soul $\rangle$ (Seele), not $\langle$ spirit $\rangle$ (Geist). Exactly fitting for this description is the article about 〈dramatic in a concise $C O D$, which runs as follows: "fit for theatrical representation, sudden, striking, impressive."

Let us consider more minutely several original key words as clues to the symbolism. The entire earth, symbolised as crust of phantoms about life and world, made solid by our egocentric attachments, quivers tremulously and explodes, and 60.000 bodhisattvas of the underground-world gush out all of a sudden. (In this case, one must regard closely the original meaning of bodhi (enlightenment) and sattva (essence). The symbolism of 60.000 , deriving from two Indian classics is already mentioned.) The differenciating working of our egocentric intellect from circumstances stops with the dis- 
appearance of subject and object, producing a sereine state of mind. $\langle\bar{A} k \bar{a}$ śa $\rangle$ means an ether - like transparent vacuity, and has in itself nothing intentional to work out to the outside world, while what it produces, on the contrary, presupposes a tremendous function, by which one realises a righteousness. 〈Ākāśa $\rangle$ itself has no functional attributes, such as I. Kant regarded as 〈unifying power of reason $\left.{ }^{8)}\right\rangle$. It is not a neologism of the Lotus Sütra Proper, but its source is found in the ChāndogyaUpanișad:: "Now in this Brahmapura is a veśma (dwelling), a small pundarīka, in which a small ākāśa is, ....the very being in this ākāśa is what one seeks for and wants to know." (8.1.1). The real value of the original author of Hokke Proper consists in creating 〈bodhi $\rangle\langle$ sattva $\rangle$ in place of $\langle\bar{a} t m a n\rangle$ as $\langle$ the very being , against the traditionally assumed association .

Seeking to explain the symbolism of this term 〈ākāśa〉, we should comprehend the changes, which come about by the influence of ākāśa's exercises upon the working of five skandha, behind the ordinary mental phenomena.

When we analyse and consider speculatively even simple and familiar phenomena, which go by only in one second, we can hardly imagine what an innumerable complicated actions take place there in the meantime. Accordingly, when we transpose speculatively and analytically our each of our affairs deeply to its composing factors through a converse procedure to our daily idea of time, by distributing it to the unit, we can count it with an enormous span time. The 〈pañcāśat〉 (50) symbolises the five skandha. The kaleidoscopic scene of changes, when the momently reations of five skandha's working pervade thoroughly the ākāśa, has been described. The genuine symbolism of this 〈pañcāśad-antara-kalpa〉 in this text does not express a temporal period. It is the very coexistence of both moment and eternity, and of both here and there As it demonstrates the potentiality of becoming Buddha of five skandha in the ākāśa, the Śākyamuni's preaching of Saddharma = Upāya-kauśalya (Skilfull Access) as Buddha is nothing but the fruits, which this potentiality bears. All members of the instructor and the instructed in the assembly are thoroughly penetrated by the serene state of mind of the Bodhisattvas from the underground. Subsequently the situation is symbolically expressed in the manner of 〈fifty- inner-kalpa, silent meditation〉, in order to call the attention to the situation where actions of five skandha's working, neither subjectively nor objectively, take 
place. It is the manifestation of the very completion of samskāra (ṛddhyabhi-sampkāra), which corresponds to the ultimate state of mind in Buddha's latest days: vayadhammā saṃkhārāa).

(To be continued.)

\section{[Notes]}

1) This period corresponds almost to that of following publications: 雜誌『一』 (hereinafter abridged as 『一』富永先生の會·昭和 12〜19年); 富永半次郎著 / 大野達之助・ 千谷七郎・風間敏夫ほか編 『蓮華展方 - 原述作者の法華經(梵和對譯)』(昭和27年); 富永牛次郎著『釋迦佛陀本紀余論』(全21冊 昭和29 38年)

2） 小谷幸雄「世界の中の佛陀現象 富永牛次郎の人間學的事跡】『印度學佛教學研究』 第47卷 - 2號 平成11年3月 / 252-257頁

4) 『一』 vol.5 pp.l8-19

5) SACRED BOOKS OF THE EAST, EDITED BY F. MAX MÜLLER vol.2l, THE SADDHARMAPUNDRİKA OR THE LOTUS OF THE TRUE LAW, translated by $\mathrm{H}$. Kern/ Motilal Banarsidass, Delhi etc. 1980: p.227

6) ibid. p.236

7) Ludwig Klages : Geist und Leben (SW 3 Philosophie III) Bouvier / Bonn, 1974 S.593

8）富永牛次郎述 横澤高記筆 『國體の信念 付·根本法華』 承謹會 昭和17年 216頁 cf. The title of Achter Abschnitt: "Regulatives Prinzip der reinen Vernunft in Ansehung der kosmologischen Ideen" / Zweites Hauptstück / Zweites Buch / Zweite Abteilung / Zweiter Teil / I. TRANSZENDENTALE ELEMENTARLEHRE in the KRITIK DER REINEN VERNUNFT by Imanuel Kant; reclam / Stuttgart 1966

9) 『—vol.36 pp.18-21; vol.42 pp.24-25

This paper was prepared by partially correcting an unpublished manuscript, which had been orally presented during the 5th International Lotus Sūtra Conference (4-6 May, 2002, Marburg), entitled "A Biocentric Drama upon the Stage in the Middle-Heaven - chiefly from the Contemplation of the Ratna-stūpa to the Issue of 60.000 Bodhisattvas". We also tried to avoid the overlapping with what was previously reported in this academic review: "The Symbolism of Hokke-Proper - Morphological Studies on Saddharma Pundarïka Sütra by a Private Scholar-(JOURNAL OF INDIAN AND BUDDHIST STUDIES, Vol. LI. No.l.Dec.2002, pp.470-473)

〈key words〉 biocentric, saddharma $(<$ The edict of King Aśoka), puṇạarika $(<$ ChāndogyaUpanișad), ṛddhy abhi-saṃskāra

(Professor Emeritus, Risshō University) 